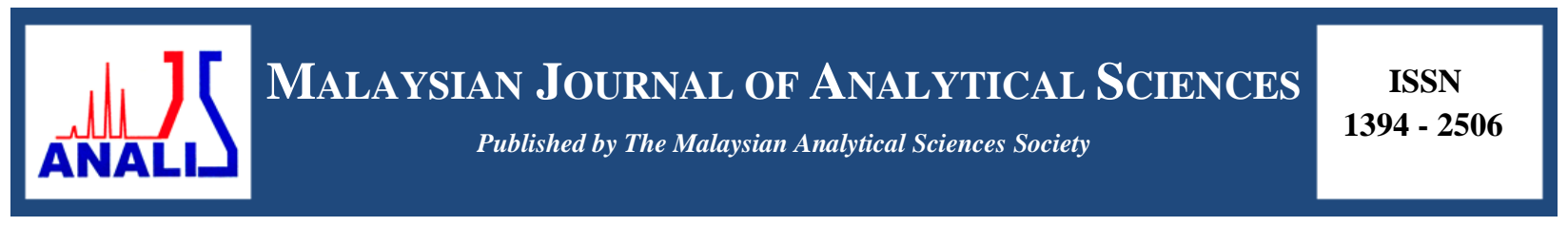

\title{
MENGKUANG FIBER REINFORCED THERMOPLASTIC NATURAL RUBBER COMPOSITES: INFLUENCE OF RUBBER CONTENT ON MECHANICAL PROPERTIES AND MORPHOLOGY
}

\author{
(Komposit Termoplastik Getah Asli Diperkuat Serabut Mengkuang: Pengaruh Kandungan \\ Getah ke atas Sifat Mekanik dan Morfologi)
}

\author{
Wan Zarina Wan Mohamed ${ }^{1,2}$, Azizah Baharum ${ }^{1,3 *}$, Ishak Ahmad ${ }^{1,3}$, Ibrahim Abdullah ${ }^{4}$, Nurzam Ezdiani Zakaria ${ }^{1}$ \\ ${ }^{I}$ School of Chemical Sciences and Food Technology, Faculty of Sciences and Technology, \\ Universiti Kebangsaan Malaysia, 43600 UKM Bangi Selangor, Malaysia \\ ${ }^{2}$ Faculty of Engineering and Life Sciences, \\ Universiti Selangor, 45600 Bestari Jaya Selangor, Malaysia \\ ${ }^{3}$ Polymer Research Center, Faculty of Science and Technology, \\ Universiti Kebangsaan Malaysia, 43600 UKM Bangi Selangor, Malaysia \\ ${ }^{4}$ Academy Sciences of Malaysia, 50480 Kuala Lumpur, Malaysia \\ *Corresponding email: azeiss@ukm.edu.my
}

Received: 20 July 2017; Accepted: 28 April 2018

\begin{abstract}
This paper presents the influence of rubber on mengkuang (MK) reinforced thermoplastic composites as the rubber content appeared to increase at low fibre loading of $10 \% \mathrm{MK}$ and high fibre loading of $30 \% \mathrm{MK}$. The MK fibre was blended with high density polyethylene (HDPE) and natural rubber (NR) through melt blending via internal mixer. The MK composites at $10 \%$ MK fibre loading exhibited higher tensile strength, tensile strain at break, and impact strength; but lower tensile modulus than MK composites at $30 \%$ fibre loading. Both fibre contents showed that the tensile strength and the tensile modulus decreased, while tensile strain at break and impact strength seemed to increase as the rubber content increased up to $40 \%$. Field emission scanning electron microscopy (FESEM) micrograph was employed to observe the fibre dispersion, as well as physical interactions between the fibre and the matrix. This study showed that the effects of MK fibre loading on mechanical properties and morphology were influenced by rubber content.
\end{abstract}

Keywords: rubber, polymer composites, mengkuang fibre, mechanical properties, morphology

\section{Abstrak}

Kertas kerja ini membentangkan pengaruh getah ke atas komposit termoplastik diperkuat serabut mengkuang (MK) dengan peningkatan kandungan getah pada muatan serabut rendah MK 10\% dan muatan serabut tinggi MK 30\%. Serabut MK telah diadun bersama polietilena berketumpatan tinggi (HDPE) dan getah asli (NR) melalui pengadunan lebur dengan pencampur dalaman. Komposit MK pada muatan serabut 10\% menunjukkan kekuatan regangan, kekuatan terikan pada takat putus, dan kekuatan hentaman yang lebih tinggi; tetapi modulus regangan yang rendah berbanding komposit MK pada muatan serabut $30 \%$. Kedua-dua muatan serabut menunjukkan kekuatan regangan dan modulus regangan menurun, sementara kekuatan terikan regangan takat putus dan kekuatan hentaman seperti meningkat dengan pertambahan kandungan getah sehingga 40\%. Sebaran serabut MK dan interaksi fizikal antara serabut dan matrik telah diperhati menerusi mikroskop elektron imbasan pancaran medan (FESEM). Kajian telah menunjukkan kesan muatan serabut MK terhadap sifat mekanikal dan morfologi komposit mengkuang dipengaruhi oleh kandungan getah.

Kata kunci: getah, komposit polimer, serabut mengkuang, sifat mekanik, morfologi 


\section{Wan Zarina et al: MENGKUANG FIBER REINFORCED THERMOPLASTIC NATURAL RUBBER COMPOSITES: INFLUENCE OF RUBBER CONTENT ON MECHANICAL PROPERTIES AND MORPHOLOGY}

\section{Introduction}

The global economic growth has generated new ideas, new technologies, innovative approaches, as well as new requirements and demands in many fields. Similar circumstances occur in the polymer composites world. The growing demands for polymer composites in many areas seem to replace the use of metals, glass, wood, and other materials [1,2]. The shortage of these materials is an advantage to the polymer composites to extend its applications. Polymer composites offer advantages of a wide range of properties from hard to soft, cheap to expensive, and low temperature to high temperature applications [3, 4]. Polymer composites can also be divided into semi biodegradable and fully biodegradable [5]. The combination of Natural Rubber (NR) and Mengkuang (MK) fibre as biodegradable materials with high density polyethylene (HDPE) as non-biodegradable material has found its use in polymer composites.

Selecting polymer matrices and fillers from the polymer composite blends is important to select a favourable polymer composite property. Each component in the polymer blends contributes its attributes in polymer composites. Polymer composites heavily depend on materials selection to cater to the necessity and the performance to be developed. The correct material selection and the suitable ratio used in the polymer composite blending, in terms of polymer matrix, reinforcement, and interphase, may produce extraordinary results for certain applications. In fact, polymer matrices have always dominated the properties of polymer [6]. Polymer matrix supports the reinforcement fibres, binds the fibres, and grasps the stress transferred. Besides, several plant fibres have been used as reinforcement filler in polymer composites. According to Monteiro et al. [7] and Fortea-Verdejo et al. [8], the mechanical properties of different types of plant fibres differ significantly due to dissimilar percentages of components in the fibres. Meanwhile, several studies that have looked into polymer matrix, reinforcement, and interface, have developed advance technologies in polymer composites. The relationships between each component, behaviour, and the responses after blending have been investigated with unlimited aspects [9-11].

Furthermore, the mechanical properties and the morphology of polymer composites are strongly influenced by fibre shape, chemical structure of fibre, fibre size, fibre concentration, fibre orientation and dispersion, as well as interactions of matrix-matrix, matrix-fibre, and fibre-fibre. The interaction of matrix-matrix is referred as miscibility of polymers, while the interaction of matrix-fibre is the compatibility of polymers. In addition, Van Der Waals forces and hydrogen bonding reflect the fibre-fibre physical interactions. In fact, many kinds of chemicals have been used as interphase for immiscible polymer blends, such maleic anhydride, dicumyl peroxide, N,N'-m-phenyl dimaleimide (HVA-2), and silane.

HDPE and NR are immiscible polymer blends. Therefore, the incorporation of NR in the blend form suggests significant physical interactions. A research study carried out by Ahmad et al. [12] indicated that the HDPE/NR blend gave the best properties at 40/60 composition. However, the addition of MK fibre to the polymer HDPE/NR blends exhibits varying effects upon the polymer composite blends. Therefore, this study focused on the influence of rubber upon MK composites, at low MK fibre loading and high MK fibre loading. This study excluded other additives or compatibilizer to serve as a preliminary study for further researches.

\section{Materials}

\section{Materials and Methods}

In this study, HDPE and NR were used as the polymer matrices. HDPE with a density of $0.95 \mathrm{~g} / \mathrm{cm}^{3}$, melt flow rate (MFR) of $1.1 \mathrm{~g} / 10 \mathrm{~min}$, and $T_{\mathrm{m}}$ at $135{ }^{\circ} \mathrm{C}$ had been supplied by Polyethylene Malaysia Sdn Bhd (Malaysia). Meanwhile, NR with Standard Malaysia Rubber grade SMR-L was obtained from Felda Rubber Industries Sdn Bhd (Malaysia). The mengkuang leaves were harvested in Bangi (Selangor, Malaysia), while the MK fibre had been prepared in the laboratory of Universiti Kebangsaan Malaysia.

\section{Fibre preparation}

The dried mengkuang leaves were ground with a universal cutting mill (Model-Pulverisette 19, Fritsch) (Germany). The fibres were immersed in tap water for another 3 days with the water changed frequently. Next, the fibres were dried at room temperature for 3 days, and then, oven-dried at $80{ }^{\circ} \mathrm{C}$ for 24 hours to remove moisture by using 
Universal Oven (Memmert, Model UFB400, Germany). After that, the fibres were sieved at size $125-250 \mu \mathrm{m}$ using a sieve (Retsch Test Sieve, Model ZM200).

\section{Composite Preparation}

The HDPE and the NR had been melt blended using an internal mixer (Model-Haake Rheomix R600) (Germany). The processing temperature was set at $135{ }^{\circ} \mathrm{C}$, while the rotation speed was fixed at $50 \mathrm{rpm}$ for 15 min. Prior to blending, the fibre was oven-dried for $2 \mathrm{~h}$ at $105{ }^{\circ} \mathrm{C}$ to eliminate moisture. After blending, the first fibre was added after $3 \mathrm{~min}$, followed by NR, and then, HDPE was added after $5 \mathrm{~min}$. The samples were compressed for $10 \mathrm{~min}$ at $145{ }^{\circ} \mathrm{C}$ under $8 \mathrm{GPa}$ pressure using a hot press to produce $1-\mathrm{mm}$ and 3-mm thick sheets for tensile and impact testing, respectively. The experimental design of polymer blends is as shown in Table 1.

\section{Mechanical Characterisation}

Ten specimens for tensile test were cut with dumbbell cutter JIS K-6251-6 (Model DMK-1000-D) (Japan). The tensile properties were measured by using a universal testing machine (Instron, Model-5566) (USA) with a $1 \mathrm{kN}$ load cell at $50.0 \mathrm{~mm} / \mathrm{min}$ crosshead speed, in accordance to ASTM 412-98a type B (2004). Notched impact strength was measured by using a pendulum digital universal fractoscope machine (Tinius Olsen, Model - IT 504), (United Kingdom), by adhering to ASTM D 256-04 (2004). On the other hand, five specimens were cut at dimensions of 65 $\times 12.7 \times 3.0$ (length $\times$ width $\times$ thickness) $\mathrm{mm}^{3}$ with $0.25 \mathrm{~mm}$ depth notch for each specimen. The impact test energy was performed at 2 joules. The impact specimens were drenched in liquid nitrogen for $1 \mathrm{~min}$ before performing the test in such a manner so as to completely break the specimens.

Table 1. The experimental design of polymer blends

\begin{tabular}{|c|c|c|c|c|c|c|}
\hline \multicolumn{7}{|c|}{ Polymer Matrix /MK Fibre 90/10 } \\
\hline MK Fibre: $10 \%$ & & 10 & 10 & 10 & 10 & 10 \\
\hline \multirow{2}{*}{ Polymer Matrix: $90 \%$} & HDPE & 100 & 90 & 80 & 70 & 60 \\
\hline & NR & 0 & 10 & 20 & 30 & 40 \\
\hline \multicolumn{7}{|c|}{ Polymer Matrix /MK Fibre 70/30 } \\
\hline MK Fibre: $30 \%$ & & 30 & 30 & 30 & 30 & 30 \\
\hline \multirow{2}{*}{ Polymer Matrix: $70 \%$} & HDPE & 100 & 90 & 80 & 70 & 60 \\
\hline & NR & 0 & 10 & 20 & 30 & 40 \\
\hline
\end{tabular}

\section{Morphology}

The morphology of the impact fracture surfaces of the specimens was examined and analysed by using a SUPRA 55VP Model field emission scanning electron microscope (FESEM) (Germany). Cross-sections of the fractured surfaces of specimens were coated with platinum to prevent the generation of electrical charges during investigation. The specimens were observed at 100x magnification.

\section{Tensile properties}

\section{Results and Discussion}

The tensile strengths of polymer composites at 10\% MK fibre and 30\% MK fibre are shown in Figure 1. 10\% of MK fibre represents low filler loading, whereas $30 \%$ fibre loading represents high filler loading. In general, the tensile result for $10 \%$ MK fibre was higher than that for 30\% MK fibre. The blends at 10\% MK fibre loading had more polymer matrices, when compared to $30 \%$ of MK fibre loading. Hence, it can be considered that the tensile strength at 10\% MK fibre was dominated by the matrix HDPE in the blends. In fact, Rozman et al. and Jamil et al. $[13,14]$ found that increment in fibre loading did not necessarily increase tensile strength. The composite blends system without any compatibilizer suggested poor interaction between MK fibre and polymer matrices, as well as 


\section{Wan Zarina et al: MENGKUANG FIBER REINFORCED THERMOPLASTIC NATURAL RUBBER COMPOSITES: INFLUENCE OF RUBBER CONTENT ON MECHANICAL PROPERTIES AND MORPHOLOGY}

the agglomeration of the fibres. However, the addition of rubber in the blends appeared to promote physical interactions between the blends.

The tensile strength for composite blends with only HDPE and without rubber exhibited MK fibre was $18.6 \%$ higher for $10 \%$ than $30 \%$ MK fibre loading. It showed that tensile strength for both blend compositions was influenced by the properties of HDPE. The stiffness of the HDPE was further increased due to dominance of HDPE matrix in the blends with higher tensile strength.

When rubber was added into the composite blends at 10\% MK fibre loading and 30\% MK fibre loading, the results of tensile strength seemed to slowly decrease. The composite blends lost their stiffness as the content of rubber was increased. The increasing rubber content dropped the tensile strength for both polymer blends. When less MK fibre existed in the composite blends, the tensile strength was dominated by the matrices. The increasing rubber content at low loading of MK fibre caused more dilution effect by the volume taken out as the fibre entered into the composite blends. The increasing rubber content supported the tensile strength from the sudden drop at higher fibre loading; $30 \%$ MK fibre. The elasticity property of rubber held the large amount of fibres in the composites.

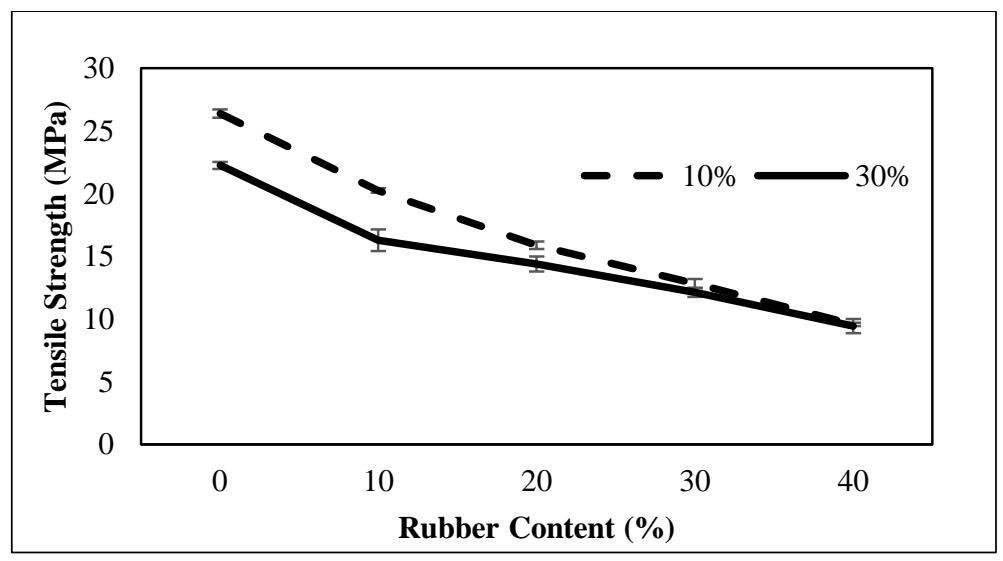

Figure 1. Tensile strength of MK composites at 10\% MK and 30\%MK

Figure 2 represents the tensile modulus of MK composites at 10\% MK fibre loading and 30\% MK fibre loading. Stiffness of natural fibre reinforced thermoplastic elastomer depends heavily on the fibre behaviour and the fibre loading. Tensile modulus of the MK composites was attributed from the fibre in the blends. Relatively, the increasing fibre increased the stiffness of the polymer composites and the tensile modulus. The graphs further display that tensile modulus of $30 \%$ of MK fibre was higher than polymer composites with $10 \%$ MK fibre for all compositions. The tensile modulus for both systems of low fibre loading and high fibre loading appeared to drop with increment in rubber content. The presence of rubber softened the composite blends and decreased the stiffness of the polymer composites. In fact, the trend of tensile modulus seemed to be similar with the pattern of tensile strength. Both fibre loading at 10\% MK and 30\% MK showed the two curves were getting closer when the rubber content was increased. Hence, rich rubber component hindered the effect of fibre loading.

Next, the wettability of the matrix on the fibre was also an additional factor that increased the stiffness in the composite blends. Similar results were reported by Zahari et al. [15], whereby increment in tensile modulus displayed better fibre dispersion in the composites. 


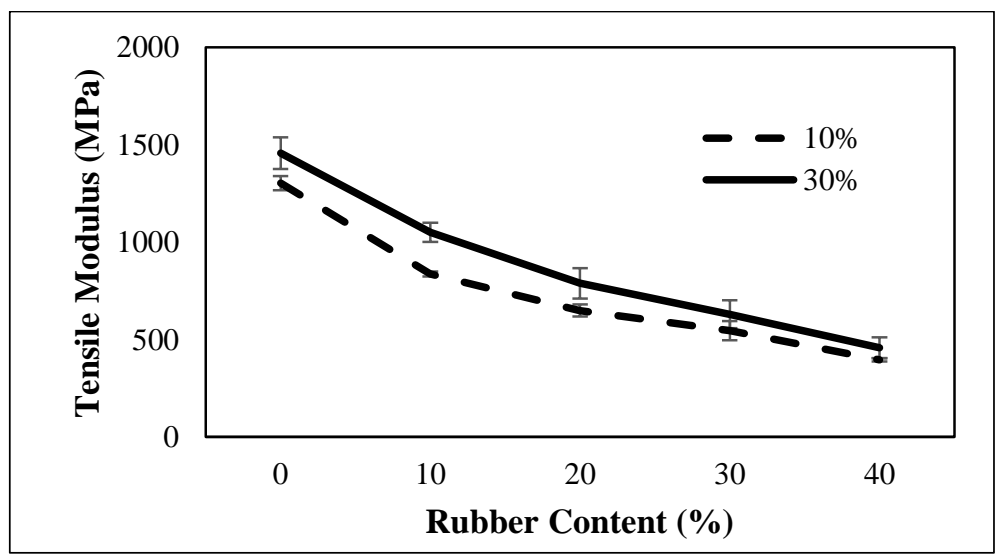

Figure 2. Tensile modulus of MK composites at $10 \%$ MK fibre and 30\%MK fibre

The outcomes of tensile strain at break are illustrated in Figure 3. The MK composites at $10 \%$ MK fibre exhibited a sharp increase with the presence of rubber content in the blends. It reached the highest point at $40 \%$ rubber with $262 \%$ improvement, when compared to the blend without rubber at the same amount of fibre content. Moreover, the polymer matrices seemed to boost their properties at low concentration of fibre. In fact, at low concentration of fibre, the MK composites were less influenced by the MK fibre, thus resulting in lower rigidity. The polymer chain of the matrix could move freely due to lower obstacles in the blends. Furthermore, the rubber matrix dominated the tensile strain at break properties at low concentration of fibre.

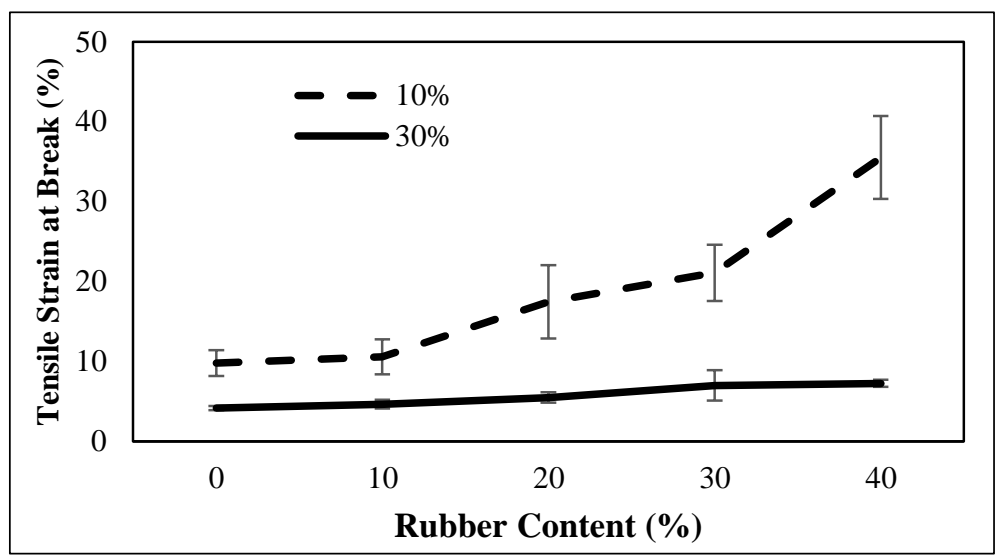

Figure 3. Tensile strain of MK composites at 10\% MK and 30\% MK

Meanwhile, at $30 \%$ of MK fibre loading, the increased rubber content had less effect on elasticity. The composites lost their elasticity as the fibre content was increased. The results showed that as the rubber content was increased, the tensile strain at break increased slightly as well. Besides, the large amount of fibre content hindered the stress that was transferred from the matrix to the fibre. The reduction of the amount of rubber matrix as the MK fibre amount was increased also caused MK composites to be more rigid. Similar results have been reported [15-17], as the presence of fibres in the polymer matrix enhanced the aspect of rigidity in the polymer composites.

\section{Impact strength}

An elastomer material, such as rubber, is well-known as a good impact absorber [12, 18]. The effect of rubber content for both polymer blends on impact strength is shown in Figure 4. The composite blends with 10\% MK fibre loading exhibited a higher impact strength, as compared to 30\% MK fibre for all compositions, with and without the presence of rubber content. Low concentration of fibre caused the polymer matrices to expose its role to absorb the 


\section{Wan Zarina et al: MENGKUANG FIBER REINFORCED THERMOPLASTIC NATURAL RUBBER COMPOSITES: INFLUENCE OF RUBBER CONTENT ON MECHANICAL PROPERTIES AND MORPHOLOGY}

immediate energy given. Besides, the presence of more matrix component increased the ability of the polymer composites to absorb energy. Hence, more matrix offers more toughness in the polymer composites.

The impact strength of $30 \%$ MK fibre loading seemed to slowly increase with the increasing rubber content in the composite blends. Similar result is also reported by El-Shekeil et al. [19] in their research on kenaf composites. The existence of fibre decreases the local motion of polymer chain. A large number of fibre initiates more crack propagation between the matrix and the fibre. However, the presence of rubber matrix appeared to reduce all those effects and supported the weak interaction between the MK fibre and the matrices. Furthermore, due to polarity factors, the tendency for the interaction between fibre and fibre is more likely to occur, when compared to the interaction between the polymer matrices. This phenomenon provides more probability for fibres agglomeration, aside from reducing the ability of composites to absorb the energy given.

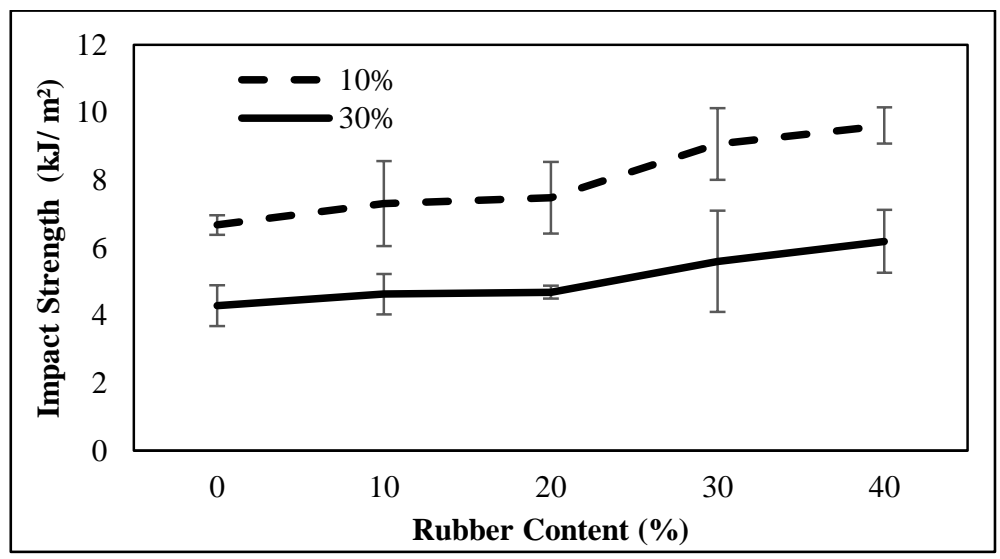

Figure 4. Impact strength of MK composites at $10 \% \mathrm{MK}$ and $30 \% \mathrm{MK}$

\section{Morphology}

Figure 5(a) presents the FESEM micrograph images of fracture surface impact test performed upon MK composites with the presence of $10 \% \mathrm{NR}$ at $10 \%$ MK fibre loading at 100x magnification, whereby a rough surface is observed with broken fibres and fibre sites. More fibres appear to disperse throughout the matrices. Next, Figure 5(b) illustrates the FESEM micrograph images of fracture surface impact test performed on MK composites with the presence of $10 \%$ NR at 30\% MK fibre loading at 100x magnification, in which more MK fibre is noted throughout the matrices. Moreover, a lot of fibre agglomeration had been detected with vast fibre bundles. The tensile strength also dropped due to fibre agglomeration [20]. Meanwhile, Figure 6(a) shows the FESEM micrograph images of fracture surface impact test performed on MK composites with $40 \%$ NR at 10\% MK fibre loading at 100x magnification. The MK fibres were found to be well-dispersed in the composite blends. Figure 6(b) displays the FESEM micrograph images of fracture surface impact test performed on MK composites with $40 \%$ NR at $30 \%$ MK fibre loading at 100x magnification. This resulted in more MK fibre with a lot of fibres in bundles that were welldispersed in the matrices. Uneven fracture surface indicates the effect of rubber holding the MK fibre. The rubber phase was also obviously deposited on the surface of MK fibre, which signified physical interactions between MK fibre and rubber phase at high rubber content. 

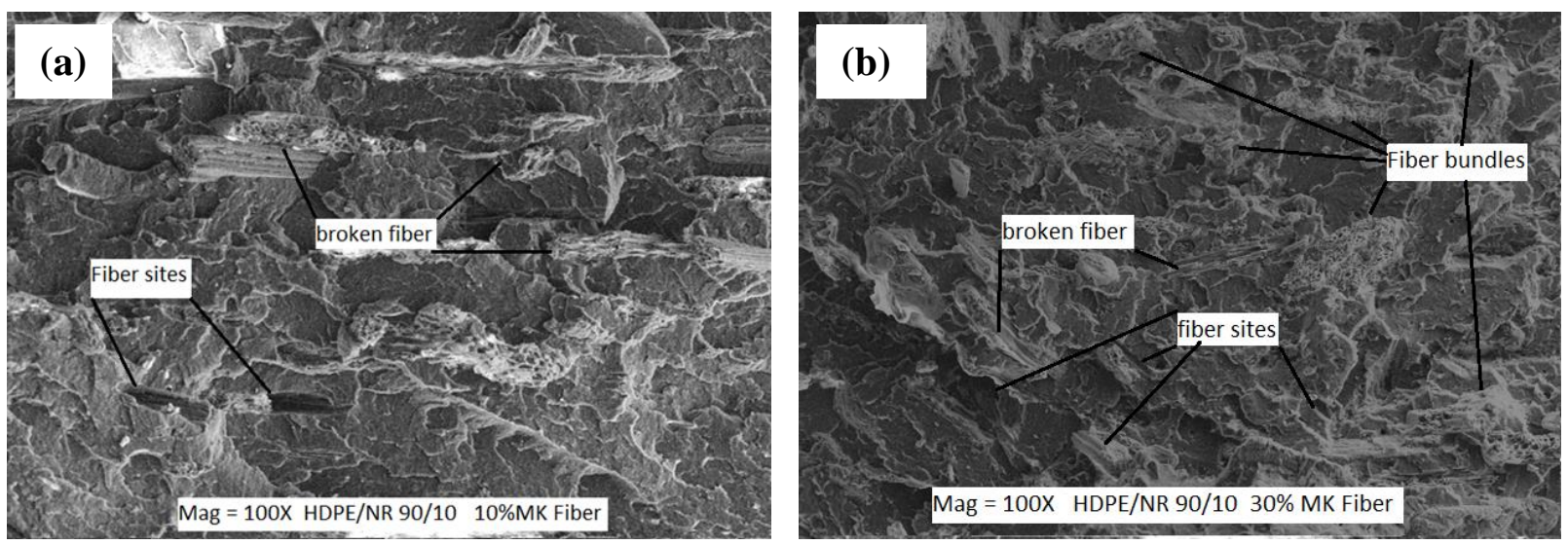

Figure 5. FESEM micrograph images of impact fracture surface on MK composites a) $10 \%$ rubber content and $10 \% \mathrm{MK}$ fibre at $100 \times$ magnification, b) $10 \%$ rubber content and $30 \%$ MK fibre at $100 \times$ magnification
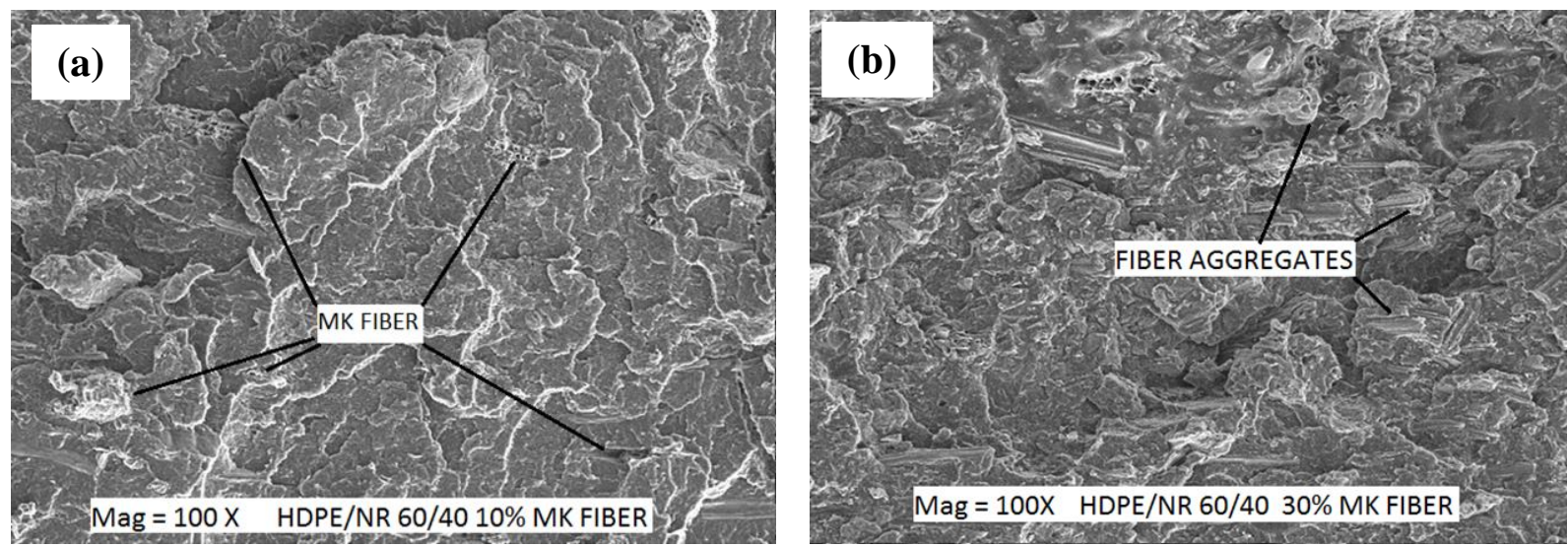

Figure 6. FESEM micrograph images of impact fracture surface on MK composites a) $40 \%$ rubber content and $10 \%$ MK fibre at 100× magnification, b) $40 \%$ rubber content and 30\% MK fibre at 100× magnification

\section{Conclusion}

Based on the results of this study, NR content strongly influenced the mechanical properties and the morphology of MK composites. The increasing rubber content in the composite blends improved their elasticity and toughness attributes. The influence of MK fibre loading upon tensile strength and tensile modulus of MK composite blends slowly diminished at high rubber content, while the morphology displayed physical interactions between fibre and matrices for the composite blends.

\section{Acknowledgement}

The authors wish to acknowledge Universiti Kebangsaan Malaysia (UKM), Universiti Selangor (UNISEL), as well as the Malaysian Ministry of Science, Technology, and Environment, for sponsoring the research under the IRPA scheme 03-01-02-SF1000, Fundamental Research Grant Scheme (FRGS/2/2014/TK04/UKM/02/1), including Selangor State Government, PORCE UKM, and CRIM UKM for the technical support and facilities extended. 


\section{Wan Zarina et al: MENGKUANG FIBER REINFORCED THERMOPLASTIC NATURAL RUBBER COMPOSITES: INFLUENCE OF RUBBER CONTENT ON MECHANICAL PROPERTIES AND MORPHOLOGY}

\section{References}

1. Saheb, N. D. and Jog, J. P. (1999). Natural fiber polymer composites: A review. Advance Polymer Technology, 18(4): 351-363.

2. Joshi, S., Drzal, L., Mohanty, A. and Arora, S. (2004). Are natural fiber composites environmentally superior to glass fiber reinforced composites?. Composite Part A: Applied Science and Manufacturing, 35(3): 371-376.

3. Alves, F. M. E., Pereira, T. V. C. and Gomes, O. D. F. M. (2013). The effect of fiber morphology on the tensile strength of natural fibers. Journal of Materials Research and Technology, 2(2): 149-157.

4. Tezara, C., Siregar, J. P., Lim, H. Y., Fauzi, F. A., Yazdi, M. H., Moey, L. K. and Lim, J. W. (2016). Factors that affect the mechanical properties of kenaf fiber reinforced polymer: A review. Journal of Mechanical Engineering and Sciences, 10(2): 2159-2175.

5. John, M. J., Varughese, K. T. and Thomas, S. (2008). Green composites from natural fibers and natural rubber: effect of fiber ratio on mechanical and swelling characteristics. Journal of Natural Fibers, 5(1): 47-60.

6. Thakur, V. K., Thakur, M. K. and Gupta, R. K. (2014). Review: Raw natural fiber-based polymer composites. Internatinal Journal of Polymer Analysis and Characterization, 19(3): 256-271.

7. Monteiro, S. N., Lopes, F. P. D., Ferreira, A. S. and Nascimento, D. C. O. (2009). Natural-fiber polymer-matrix composites: Cheaper, tougher, and environmentally friendly. Polymer-Matrix Composites, 61(1): 17-22.

8. Fortea-Verdejo, M., Bumbaris, C., E., Burgstaller, C., Bismark, A. and Lee, K. Y. (2017). Plant fibrereinforced polymers: Where do we stand in terms of tensile properties?. International Materials Reviews, 62(8): 441-464.

9. Hassaini, L., Kaci, M., Touati, N., Pillin, S., Kervoelen, A. and Bruzaud, S. (2017). Valorization of olive husk flour as a filler for biocomposites based on poly(3-hydroxybutyrate-co-3-hydroxyvalerate): Effects of silane treatment. Polymer Testing, 59: 430-440.

10. Puglia, D., Sarasini, F., Santulli, C. and Kenny, J. M. (2017). Manufacturing of natural fiber/agrowaste based polymer composites. Green Biocomposites, Springer: pp. 125-147.

11. Preet Singh, J. I., Dhawan, V., Singh, S. and Jangid, K. (2017). Study of effect of surface treatment on mechanical properties of natural fiber reinforced composites. Material Today Proceeding, 4(2):2793-2799.

12. Ahmad, S., Abdullah, I., Sulaiman, C. S. and Kohjiya, S. (1994). Natural rubber-hdpe blends with liquid natural-rubber as a compatibilizer. I. thermal and mechanical-properties. Journal of Applied Polymer Science, 51:1357-1363.

13. Rozman, H. D., Tan, K. W., Kumar, R. N., Abubakar, A., Mohd Ishak, Z. A. and Ismail, H. (2000). The effect of lignin as a compatibilizer on the physical properties of coconut fiber- polypropylene composites. European Polymer Journal, 36: 1483-1494.

14. Jamil, M. S., Ahmad, I. and Abdullah, I. (2006). Effects of rice husk filler on the mechanical and thermal properties of liquid natural rubber compatibilized high-density polyethylene/natural rubber blends. Journal of Polymer Research, 13(4):315-321.

15. Zahari, W. Z. W., Badri, R. N. R. L., Ardyananta, H., Kurniawan, D. and Nor, F. M. (2015) Mechanical properties and water absorption behavior of polypropylene / ijuk fiber composite by using silane treatment. Procedia Manufacturing, 2: 573-578.

16. Stelescu, M-D., Manaila, E., Craciun, G. and Dumitrascu, M. (2014). New green polymeric composites based on hemp and natural rubber processed by electron beam irradiation. The Scientific World Journal, 2014: 1-13.

17. Chen, R. S., Ahmad, S. and Gan, S. (2016). Characterization of rice husk-incorporated recycled thermoplastic blend composites. BioResources, 11(4): 8470-8482.

18. Ibrahim, A. and Dahlan, M. (1998). Thermoplastic natural rubber blends. Progress in Polymer Science, 23: 665-706.

19. El-Shekeil, Y. A., Sapuan, S. M., Khalina, A., Zainudin, E. S. and Al-Shuja'a, O. M. (2012). Influence of fiber content on the mechanical and thermal properties of Kenaf fiber reinforced thermoplastic polyurethane composites. Journal of Thermal Analysis and Calorimetry, 109: 299-303.

20. Syafri, R., Ahmad, I. and Abdullah, I. (2011). Effect of rice husk surface modification by LENR the on mechanical properties of NR/HDPE reinforced rice husk composite. Sains Malaysiana, 40(7): 749-756. 